\title{
Floral Initiation in Red Firespike (Odontonema strictum): Effects of Photoperiod and Duration of Short Day Exposure
}

\author{
Amir Rezazadeh ${ }^{1}$ and Richard L. Harkess ${ }^{2}$ \\ ${ }^{1}$ Mississippi State University, Coastal Research and Extension Center, Poplarville, MS 39470, \\ ${ }^{2}$ Mississippi State University, Department of Plant and Soil Sciences, Starkville, MS 39759 \\ *Corresponding author
}

\section{A B S T R A C T}

\section{Keywords}

Floral initiation,

Floral bud

differentiation,

Reproductive phase,

Short-day

Article Info

Accepted:

18 April 2019

Available Online:

10 May 2019
Red firespike (Odontonema strictum) is a tropical flowering plant that has a potential as a new flowering potted plants for its attractive red inflorescence. Flowering and morphology of red firespike were evaluated in response to photoperiod. In Expt. 1, morphology and growth characteristics of firespike were evaluated in response to photoperiod. Plants were propagated from semi-softwood cuttings and grown under long days (LD). Plants were exposed to short days (SD) of $9 \mathrm{~h}$ for $0,4,8,12,16,20,24,28$ or 32 days. Plant height and growth index increased as the number of SD increased. Plants that received 16 or more SD reached anthesis earlier than plants grown under fewer SD. The number of plants that flowered was higher in 32 SD than in lower SD. In Expt. 2, plants were placed in SD for 0, $8,16,24$ or 32 days and then apical meristems were examined histologically to determine the pattern of flowering in firespike during the time prior to anthesis. Plants that received only 8 SD showed early floral initiation and after 16 SD, meristems continued reproductive differentiation even when returned to LD. Under the experimental conditions tested, the most rapid, uniformed, and complete flowering of firespike occurred when plants received 24-32 days of inductive signal (SD).

\section{Introduction}

Initiation of flowering is a highly regulated process. Plants switch from vegetative to reproductive development by floral induction, which depends on endogenous and environmental signals such as day length (Erwin, 2006; Noy-Porat, et al., 2009). Thus, time of floral initiation and anthesis can be predictable that is important for commercial growers. The ability to predict when a certain plant developmental stage will occur is valuable in production and in planning the appropriate time for marketing (Challa, 1985). The current market often requires flowering plants produced for a specific date or holiday such as Christmas. For commercially important plants, it is inevitable to construct prediction models for the flowering of these plants (Erwin and Heins, 1990).

One of the most important events in the life cycle of flowering plants is the transition from vegetative to reproductive growth. Floral 
induction and initiation are the first stages preceding floral bud differentiation. Induction is a key developmental stage controlled by external and internal factors acting to direct flowering (Wang et al., 2014). Many plant species have the ability to initiate flowering in response to environmental factors such as change in daylength (photoperiod). Daylength is a controlling factor for flower induction and initiation for many plants. Plants flowering in response to photoperiod have been classified as long-day (LD), day neutral (DN) and shortday (SD) plants (Thomas and Vince-Prue, 1997). Long day plants flower when the daylength exceeds their critical photoperiod. Day neutral plants are insensitive to daylength and SD plants flower when the daylengths are less than a critical photoperiod. Short day and LD plants may also be categorized as facultative or obligate for photoperiod requirement where flowering is hastened by photoperiod in facultative plants or a critical photoperiod is required in obligate plants (Thomas and Vince-Prue, 1997). Critical photoperiod is the factor that if met, induce flowering in both long day and short day plants.

However, if plants receive insufficient inductive signal, floral meristem revers to producing leaves instead of developing reproductive organs, a phenomenon called flower reversion (Battey and Lydon, 1990). If short-day plants are transferred to the long-day condition after floral induction or initiation, floral development can be inhibited, particularly if the transfer occurs early in floral development (Adams et al., 1998). One way to determine the minimum number of inductive photoperiodic cycles necessary for floral initiation is to limit the inductive photoperiod or transferring deferent numbers of plants back to the non-inductive condition (Damann and Lyons, 1993). Daylength response varies widely between species and is one of the most important environmental factors controlling floral induction and initiation (Colasanti and Sundaresan, 1996). A small change in daylength leads to change from vegetative growth to reproductive development (Runkle and Heins, 2006). In some tropical plants, floral induction starts in response to decline in photoperiod of $30 \mathrm{~min}$ or less.

Red firespike is an attractive plant commonly cultivated as a background plant in gardens and sometimes is used to make hedges in tropical and subtropical climates (Watkins, 1975; Whistler, 2000). It is native to the tropical and sub-tropical regions of Central America (Daniel, 1995). The plant has potential as a flowering potted plant due to its attractive red inflorescence, dark green foliage, and natural bloom time (Rezazadeh et al.,. 2015). Wang et al., (2014) showed that floral transition is roughly predictable according to vegetative growth characteristics. The correlation between vegetative growth morphology (i.e. plant height, growth index, number of branches, etc.) and meristematic changes in the apical meristem during floral transition is important to understand production scheduling.

Previous studies on environmental factors affecting flowering of red firespike only discussed time to visible flower (Garofalo, 2002). Red firespike is reported to be a SD plant (Garofalo, 2002). However, there is currently no information available on photoperiod requirements of firespike for flower induction. Meristematic development during transition to flowering in red firespike has not been characterized nor has the timing of the events during transition from vegetative to reproductive stage been reported. The aims of the present investigation were to determine the minimum number of short-days needed to induce full flowering and to evaluate the effect of photoperiod on growth and flowering on red firespike. 


\section{Materials and Methods}

Vegetative stock plants of red firespike were maintained under LD using 4-hour night interruption lighting with $60-\mathrm{W}$ (3 to 4 $\mu$ mol.m-2.s-1) incandescent lights from 22:00 to $02: 00 \mathrm{HR}$ for 2 weeks to prevent floral initiation occurring before start of experimental treatments. On January 2014, medial, single-stemmed plants were propagated from semi-softwood cuttings of red firespike. Four weeks later, the rooted cuttings were transplanted to $15 \mathrm{~cm}$ diameter pots containing a commercial potting substrate (Sunshine Mix 1; SunGro Horticulture, Bellevue, WA) and grown under natural daylength (12 day-light hours) plus a 4-hour night interruption as described before. Plants were grown at $23 \pm 0.5{ }^{\circ} \mathrm{C}$ in greenhouse and liquid fertilizer at $200 \mathrm{ppm}$ nitrogen was provided with at each irrigations (Peters PeatLite 20-10-20; Scotts, Marysville, OH).

Two experiments were performed. In experiment 1, plants were exposed to photoperiod of $0,8,16,24$ or 32 SD before being returned to LD. Long day photoperiod was provided using $100 \mathrm{~W}$ incandescent light mounted above each bench in greenhouse. In addition, control plants were exposed to continuous LD until termination of experiment. Short-day treatments were provided in different growth chambers using a combination of cool-white fluorescent and incandescent lamps from 08:00 to 17:00 HR and irradiance was $200 \mu \mathrm{mol} \cdot \mathrm{m}^{-2} \cdot \mathrm{s}^{-1}$. The temperature and relative humidity $(\mathrm{RH})$ in growth chambers were fixed at $23^{\circ} \mathrm{C}$ and $70 \%$, respectively. Ten plants were used in a completely randomized design. Plant height (from the soil level to the top point of the plant) was measured at termination of the study. Plant growth index (GI) was calculated as $\mathrm{GI}=\pi \times($ average width/2) $2 \times$ height. Number of branches over $4 \mathrm{~cm}$ in length, days to first floret opening (days from rooting the cuttings), and number of plants reaching first floret opening (anthesis) were counted. Data were analyzed using the GLM procedure of SAS (version 9.3; SAS Institute, Cary, NC). Means were separated using the least significant difference (LSD) test at $\mathrm{P} \leq 0.05$.

In experiment 2, red firespike cuttings were rooted and grown under LD as previously described. Plants then received different photoperiod treatments of $0,4,8,12,16,20$, 24,28 or 32 SD before transfer back to LD. One group of plants as control was exposed to continuous LD.

After each SD treatments, plants were exposed to 0 or $8 \mathrm{LD}$ treatments to see if floral reversion occurs. Ten plants were used in a completely randomized design for each photoperiod treatment. Three plants from each treatment were sampled for histological study after a subsequent exposure to 0 or $8 \mathrm{LD}$. The apical meristem of the plants was excised and immediately fixed in FAA (5 parts formalin, 5 parts glacial acetic acid, 90 parts $50 \%$ ethanol) for a minimum of 14 days at $\sim 5^{\circ} \mathrm{C}$ before dehydrating in an ethanol series and embedding in paraffin for sectioning. The embedded meristems were sectioned at $10 \mu \mathrm{m}$, stained with hemalum/erythrosine, and examined under light microscopy for anatomical differences (Harkess and Lyons, 1994). The morphological characteristics of each sample were used to describe bud differentiation during transition to flowering and each differentiation phase classified numerically into different stages. Apical meristematic development was evaluated and classified into one of five stages: Stage 1) vegetative (Fig. 1A); Stage 2) floral initiation with upward rise of the tunica and corpus (Fig. 1B); Stage 3) periclinal division of cells in the central zone preceding elongation of the apical meristem (Fig. 1C); Stage 4) center of the apical bud rises upward and bract primordia appear (Fig. 1D); Stage 5) inflorescence 
development with elongated bracts subtending elongated floret primordia (Fig. 1E and $1 \mathrm{~F}$ ).

\section{Results and Discussion}

The results in table 1 demonstrate that SD resulted in increase in plant height after receiving $8 \mathrm{SD}$ compared with control plants (shortest in $23.4 \mathrm{~cm}$ ). The increase in height in response to SD is not in agreement with earlier studies with other plants such as chrysanthemum (Chrysanthemum grandiflorum) (Nxumalo and Wahome, 2010), black-eyed-Susan (Harkess and Lyons, 1994) or lisianthus (Wang, 2014).

Table.1 The effects of increasing exposure to short days on red firespike (Odontone mastrictum) plant height, growth index [GI $=\pi$ (average width/2) $2 \times$ height], number of branches over $4 \mathrm{~cm}$ in length, days to first floret opening (DFF) from planting the rooted cutting, and number of plants reaching first floret opening, (anthesis) by termination of the study

\begin{tabular}{|l|l|l|l|l|l|}
\hline SD (No.) & $\begin{array}{l}\text { Height } \\
(\mathbf{c m})\end{array}$ & GI $(\mathbf{c m 3})$ & $\begin{array}{l}\text { Branches } \\
\text { (No.) }\end{array}$ & TFF (d) & $\begin{array}{l}\text { Plants } \\
\text { reaching } \\
\text { anthesis (No.) }\end{array}$ \\
\hline $\mathbf{0}$ & $23.4 \mathrm{bz}$ & $10587 \mathrm{~b}$ & $2.8 \mathrm{a}$ & - & 0 \\
\hline $\mathbf{8}$ & $37.6 \mathrm{a}$ & $30685 \mathrm{a}$ & $2.6 \mathrm{a}$ & $147 \mathrm{a}$ & 6 \\
\hline $\mathbf{1 6}$ & $36.0 \mathrm{a}$ & $30059 \mathrm{a}$ & $3.4 \mathrm{a}$ & $135 \mathrm{~b}$ & 6 \\
\hline $\mathbf{2 4}$ & $39.4 \mathrm{a}$ & $31718 \mathrm{a}$ & $2.6 \mathrm{a}$ & $130 \mathrm{~b}$ & 8 \\
\hline $\mathbf{3 2}$ & $43.0 \mathrm{a}$ & $39806 \mathrm{a}$ & $2.4 \mathrm{a}$ & $128 \mathrm{~b}$ & 10 \\
\hline
\end{tabular}

zMeans within a column followed by the same letter are not significantly different according to the least significant difference means comparison test at $\mathrm{P}=0.05$.

Table.2 Mean stage of red firespike (Odontone mastrictum) meristematic development after exposure to inductive photoperiodic treatments (SD). Plants received 0, 4, 8, 12, 16, 20, 24, 28 or

32 SD before being transferred back to non-inductive LD (0 or 8 days). The treatments are number of SD plus additional LD before sampling for histological examination and classification into stages of meristematic development

\begin{tabular}{|c|c|c|c|c|c|c|c|c|c|}
\hline \multicolumn{2}{|c|}{ Treatment } & \multirow{2}{*}{$\begin{array}{l}\begin{array}{l}\text { Agez } \\
\text { (days) }\end{array} \\
0\end{array}$} & \multirow{2}{*}{$\begin{array}{l}\text { Stagey } \\
1.2\end{array}$} & \multirow{2}{*}{$\begin{array}{l} \pm \mathrm{SE} \\
\pm 0.1\end{array}$} & \multicolumn{2}{|c|}{ Treatment } & \multirow{2}{*}{$\begin{array}{l}\begin{array}{l}\text { Agez } \\
\text { (days) }\end{array} \\
20\end{array}$} & \multirow{2}{*}{$\begin{array}{l}\text { Stagey } \\
4.2\end{array}$} & \multirow{2}{*}{$\begin{array}{l} \pm \text { SE } \\
\pm 0.1\end{array}$} \\
\hline $\begin{array}{l}\text { SD } \\
\text { 0 }\end{array}$ & $\begin{array}{l}\text { LD } \\
\text { 0 }\end{array}$ & & & & & $\begin{array}{l}\text { LD } \\
0\end{array}$ & & & \\
\hline 0 & 8 & 8 & 1.2 & \pm 0.1 & 20 & 8 & 28 & 4.2 & \pm 0.1 \\
\hline 4 & 0 & 4 & 1.3 & \pm 0.1 & 24 & 0 & 24 & 4.3 & \pm 0.1 \\
\hline 4 & 8 & 12 & 1.3 & \pm 0.1 & 24 & 8 & 32 & 4.4 & \pm 0.2 \\
\hline 8 & 0 & 8 & 2.1 & \pm 0.1 & 28 & 0 & 28 & 4.8 & \pm 0.1 \\
\hline 8 & 8 & 16 & 2.2 & \pm 0.1 & 28 & 8 & 36 & 4.9 & \pm 0.1 \\
\hline 12 & $\mathbf{0}$ & 12 & 2.3 & \pm 0.1 & 32 & 0 & 32 & 5 & \pm 0 \\
\hline 12 & 8 & 20 & 2.4 & \pm 0.2 & 32 & 8 & 40 & 5 & \pm 0 \\
\hline 16 & 0 & 16 & 3.2 & \pm 0.1 & & & & & \\
\hline 16 & 8 & 24 & 3.3 & \pm 0.1 & & & & & \\
\hline
\end{tabular}

z Age equals the number of SD plus LD received after the start of treatments. 
Fig.1 Longitudinal sections of red firespike (Odontone mastrictum) meristems illustrating the anatomical changes during floral initiation and inflorescence development. Vegetative apical meristems are flat with a clear central zone surrounded by upright leaf primordia, 0 SD (A); after $8 \mathrm{SD}$, there was an elongated stem and bulges on both sides of the apical meristem and upward rise of the tunica and corpus indicating floral initiation (B); at $16 \mathrm{SD}$, floral development begins with periclinal division of cells in the central zone preceding elongation of the apical meristem (C); following $20 \mathrm{SD}$, inflorescence development continues as the center of the apical bud rises upward and bract primordia appear (D); multiple bract pairs connected to the procambium and subtending the floret primordia are clearly visible at $28 \mathrm{SD}(\mathrm{E})$; and advanced inflorescence development with elongated bracts subtending elongated floret primordia at 32 SD (F)
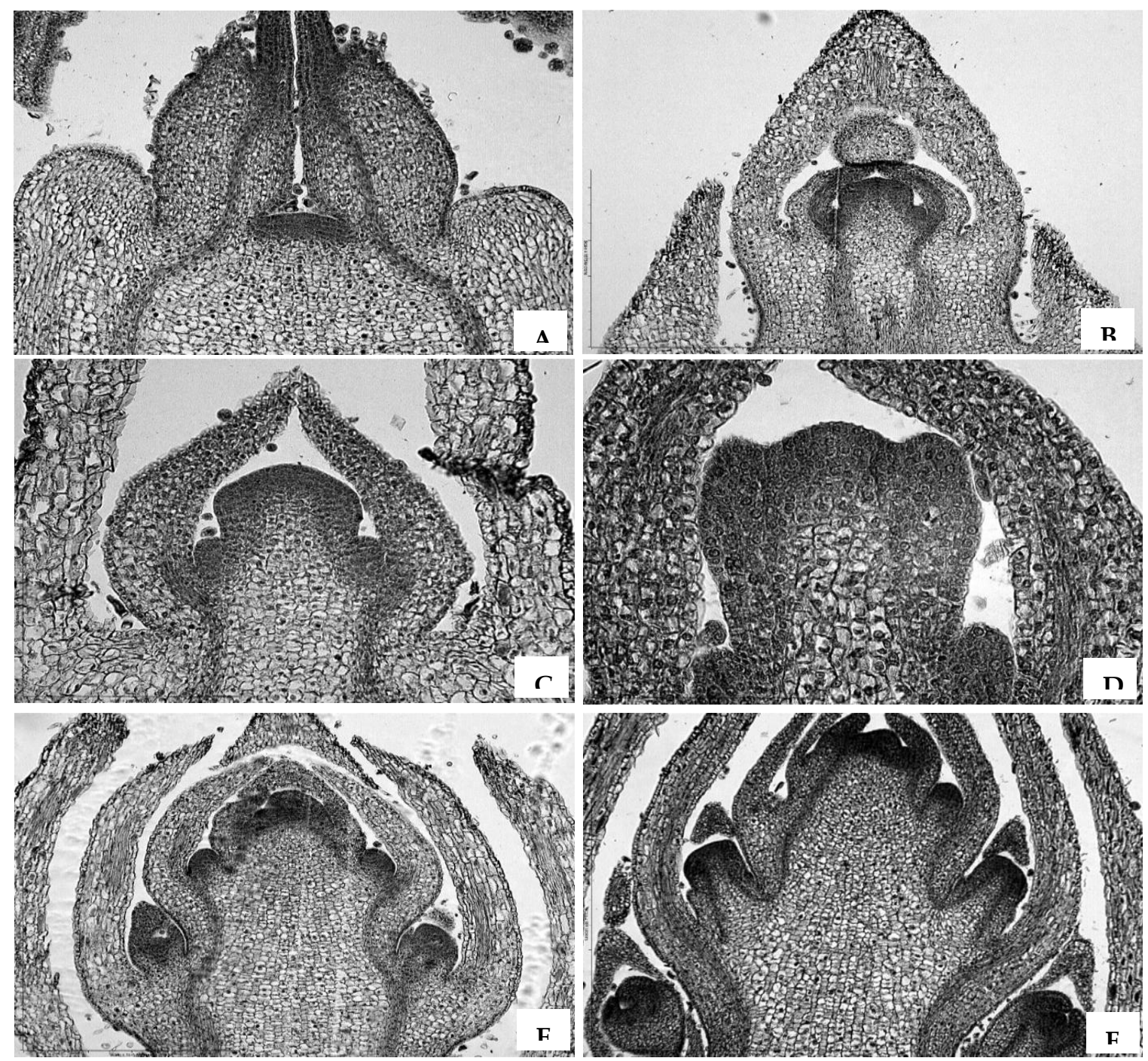

Time to the first floret decreased as plants received SD, ranging from 128 to 147 days. However, there was no significant difference in time to first floret between plants exposed to 16,24 or $32 \mathrm{SD}$. Control plants did not

flower until termination of experiment. As a results, red firespike can be defined as a SD plant that does not flower if receives less than 8 SD. This is consistent with the previous study by Garofalo (2002) reporting red 
firespike is a short-day plant. As number of SD increased from 16 to 32 , the number of plants reaching to anthesis increased from 6 to 10 (Table 1). The increased number of plants with flower with increasing SD may be attributed to more advanced floral development before being moved to noninductive LD photoperiods. The same results were also observed in black-eyed-Susan (Rudbeckiahirta) (Harkess and Lyons, 1994).

In experiment 2, development of meristem followed a specific pattern during transition to reproductive stage (Fig. 1). When plants received $0 \mathrm{SD}$, they remained vegetative in stage 1 and there was no reproductive differentiation in the apical meristem (Table 2; Fig. 1A). The vegetative apical meristem was flat with a clear central zone surrounded by upright leaf primordia. After $8 \mathrm{SD}$, there was an elongated stem and bulges on both sides of the apical meristem arising from divisions in the peripheral zone along with a dissociation of the central zone and upward rise of the tunica and corpus indicating floral initiation and transition from vegetative to reproductive growth has been started (Fig. 1B). At $16 \mathrm{SD}$, periclinal division of cells in the central zone accompanied elongation in the apical meristem. Cell division in the peripheral zone led to axillary bud growth while leaf primordia subtending the inflorescence arose from sub epidermal cellular divisions and were connected to the procambium (Fig. 1C). Following exposure to $16 \mathrm{SD}$, plants did not revert to vegetative growth even after being returned to $\mathrm{LD}$ conditions. After 20 SD, with more elongation in the central zone of the apical meristem, inflorescence development continued as the center of the apical bud rises upward and two more bract primordia appeared (Fig. 1D). Floret development had progressed to stage 5 and multiple bract pairs subtending the floret primordia were clearly visible after 28 SD (Table 2 and Fig. 1E).
Bracts were connected to the procambium while floret primordia arose as protrusions from peripheral zone tissues. After 32 SD, advanced inflorescence development with elongated bracts subtending elongated floret primordia were observed (Fig. 1F).

The primary inflorescences in red firespike arise from the terminal axis, composed of tubular red florets, and sometimes branched (Garofalo, 2002). During apical meristem elongation under SD, floret primordia initiated above bract primordia after 24 SD. Floret primordia differ from leaf or bract primordia and they appear as an outgrowth of the peripheral zone. Florets became more differentiated and visible after $32 \mathrm{SD}$. The bracts arise from sub-epidermal layers of the meristem and have a direct connection to the procambium or vascular system of the plant. Floral induction and initiation begin in the apical meristem with axillary bract and floret initiation progresses as the plant remains under SD. A delay in flowering and lack of axillary florets in plants prematurely removed from SD (observational data) indicate that continuous SD exposure may be required to maximize inflorescence size. Since leaves perceive the floral inductive signal and produce the floral stimulus in response to SD, continuous SD may be needed to produce enough stimulus for continued axillary floret initiation. The majority of plants received 24 or $32 \mathrm{SD}$, reached anthesis while plants grown under LD never flowered. Each increase in SD exposure enhanced the degree of differentiation. The present study described the pattern of anatomical changes during transition from vegetative to reproductive growth as well as number of SD required for floral induction in red firespike. Terminal inflorescence initiation began after 8 SD when the plants began the cellular switch from vegetative to reproductive growth. The process of flowering in red firespike requires approximately 24 to $32 \mathrm{~d}$ from being placed 
in inductive conditions to anthesis of the first floret.

\section{References}

Adams, S.R., Pearson, S., and Hadley, P. 1998. An appraisal of the use of reciprocal transfer experiments: assessing the stages of photoperiod sensitivity in chrysanthemum cv. Snowdon (Chrysanthemum morifolium Ramat.). J. Exp. Bot. 49:1405- 411.

Battey, N.H., and Lyndon, R.F. 1990. Reversion of flowering. Bot. Rev. 56:162-189.

Challa, H. 1985. Report from the working party crop growth models. ActaHortic. 174:169-175.

Colasanti, J., and Sundaresan, V. 1996. Control of the transition to flowering. Curr. Opin. Biotech. 7:145-149.

Damann, M.P., and Lyons, R.E. 1993. Juvenility, flowering, and the effects of a limited inductive photoperiod in Coreopsis grandiflora and C. lanceolata. J. Amer. Soc. Hortic. Sci. 118:513-518.

Daniel, T.F. 1995. Revision of Odontonema (Acanthaceae) in Mexico. Contrib. Univ. Mich. Herb. 20:147-171.

Erwin, J.E., and Heins, R.D. 1990. Temperature effects on lily development rate and morphology from the visible bud stage until anthesis. J. Amer. Soc. Hortic. Sci. 115:644-646.

Erwin, J. 2006. Factors affecting flowering in ornamental plants. In Flower Breeding and Genetics: Issues, Challenges and Opportunities for the 21st Century; Anderson, N.O., Ed.; Springer: Dordrecht, The Netherlands. pp. 7-48.

Garofalo, J.F. 2002. Short-day shrubs for fall and winter color. Univ. Florida Coop. Ext. Ser. Fact Sheet No. 38.
Harkess, R.L., and Lyons, R.E. 1994. Floral initiation in Rudbeckiahirta (Asteraceae) under limited inductive photoperiodic treatments. Amer. J. Bot. 81:1021-1026.

Noy-Porat, T., Flsishman, M.A., Eshel, A., Sandler-Ziv, D., and Kamenetsky, R. 2009. Florogenesis of the Mediterranean geophyte Narcissus tazetta and temperature requirements for flower initiation and differentiation. Sci. Hortic. 120:138-142.

Nxumalo, S.S., and Wahome, P.K. 2010. Effects of application of short-days at different periods of the day on growth and flowering in chrysanthemum (Dendranthema grandiflorum). J. Agric. Soc. Sci. 6:39-42.

Rezazadeh, A., Harkess, R.L., and Bi, G. 2015. Stimulation of lateral branching of red firespike using dikegulac sodium, benzyladenine, and pinching. HortTechnology 25:358-361.

Runkle, E.S., and Heins, R.D. 2006. Manipulating the light environment to control flowering and morphogenesis of herbaceous plants. ActaHortic. 711:5160.

Thomas, B., and Vince-Prue, D. 1997. Photoperiodism in Plants, 2nd ed.; Academic Press: New York, NY, USA, pp. 1-26.

Wang, Q., Guo, R., Zhang, C., Zhou, Z., and $\mathrm{Hu}, \mathrm{H}$. 2014. Optimal photoperiod and floral transition of Eustoma grandiflorum 'Tiramisu Double Cream'. Sci. Hortic. 175:121-127.

Watkins, J.V. 1975. Florida landscape plants, native and exotic. The University Presses of Florida, Gainesville, FL, USA.

Whistler, W.A. 2000. Tropical ornamentals, a guide. Timber Press, Inc., Portland, OR, USA.

\section{How to cite this article:}

Amir Rezazadeh and Richard L. Harkess. 2019. Floral Initiation in Red Firespike (Odontonema strictum): Effects of Photoperiod and Duration of Short Day Exposure. Int.J.Curr.Microbiol.App.Sci. 8(05): 2384-2390. doi: https://doi.org/10.20546/ijcmas.2019.805.282 